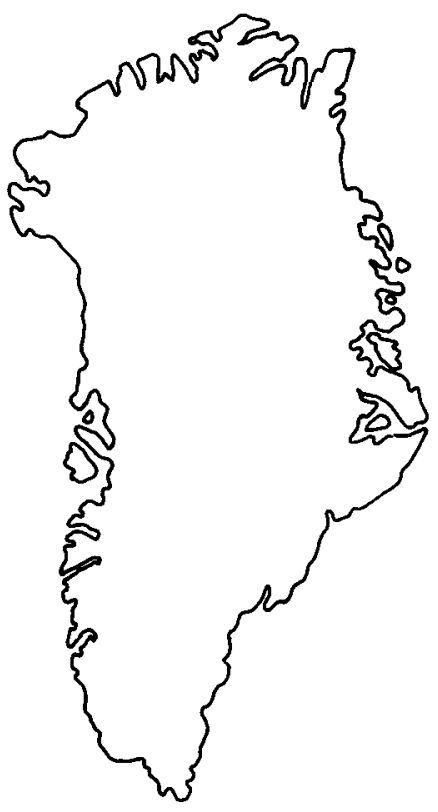

\title{
Lead isotope studies on mineral showings and ore deposits in East Greenland
}

\author{
Sven Monrad Jensen
}

\begin{abstract}
Lead isotope studies indicate an age of $680 \pm 65$ Ma for syn-diagenetic stratiform copper mineralisation in the Upper Proterozoic Eleonore Bay Supergroup (EBS) sediments. Metals in EBS-hosted veins were remobilised from local host rocks, or derived from underlying Middle Proterozoic gneisses. Tungsten-arsenic skarns associated with Caledonian granites intruded into the EBS incorporated lead mobilised from the basement gneisses mixed with Caledonian granite lead. Isotopic compositions of trace lead in sparse sulphide occurrences in North-East Greenland point to Late Archacan - Early Proterozoic sources, comparable to the local basement gneisses. Base metal mineralisation in Upper Palaeozoic - Mesozoic rocks in central East Greenland shows a limited range, in lead isotope compositions, suggesting that a large, homogeneous crustal reservoir supplied the metals, or that metals from different sources were effectively mixed. Mineralisation in Tertiary igneous rocks in the Kangerdlugssuaq area of southern East Greenland shows lead isotope evidence for contamination by material from lower crustal Archaean sources.
\end{abstract}

S. M. J., Department of Geology, University of Aarhus, DK-8000 Arhus C, Denmark. Present address: Geological Survey of Greenland, Øster Voldgade 10, DK-1350 Copenhagen K, Denmark.

The lead isotope system is unique in that it directly addresses the provenance of lead (and by inference other metals) in ore deposits. Variations in lead isotope composition within or between deposits characterise geochemical aspects and geological histories of crustal or mantle metal source regions. Lead isotopes thus place constraints on genetic models for mineralisation. Within a region, different types of mineralisation usually have distinct and characteristic ranges of lead isotope ratios. Such isotopic 'fingerprints' are useful in classifying ore deposits, by type, age and source of metals. Suites of lead isotope analyses from mineralised localities or groups of localities often plot as linear arrays in conventional diagrams for lead isotope data presentation. Linear arrays may give geochronological information (isochrons) or information about multiple sources of lead (mixing lines).

In central East Greenland and southern parts of North-East Greenland some 150 ore mineral occurrences are known (Harpøth et al., 1986). However, only the Blyklippen lead-zinc deposit at Mesters Vig has been exploited. Extensive diamond-drilling has been undertaken on several other prospects, for example the scheelite-stibnite-gold-mineralised quartz veins and breccias on Ymer $\emptyset$ and the Tertiary Malmbjerg porphyry-molybdenum stockwork (Fig. 1); at the latter test adits were also excavated. Mineralisation associated with Tertiary igneous activity has been the focus of considerable economic interest. In central East Greenland a $150 \mathrm{Mt}$ ore body with $0.23 \% \mathrm{MoS}_{2}$ was proven for the Malmbjerg porphyry-molybdenum deposit (Harpøth et al., 1986). For the Kangerdlugssuaq area in southern East Greenland (Fig. 1) molybdenum-precious metal mineralisation at Flammefjeld in the Tertiary Kangerdlugssuaq alkaline complex has been reported on by Geyti \& Thomassen (1984) and Stenstrop (1989), and the gold and platinum group element potential of Tertiary layered gabbroic intrusions and related rocks is currently under investigation (Nielsen, 1990; Nielsen \& Schønwandt, 1990; Bird et al., 1991).

The mineral potential of the northern parts of NorthEast Greenland has only been investigated on a reconnaissance basis (Jensen \& Stendal, 1990; Henriksen, 1991; Schønwandt, 1991). Known mineral showings are sparse, and are mainly confined to iron sulphides and traces of copper along Caledonian thrust and shear zones. Locally, a Proterozoic skarn was sheared and modified by metamorphic solutions in Caledonian time. Upper Mesozoic or Tertiary block faulting in the Precambrian gneisses is often accompanied by pyrite mineralisation in fault breccias, and in one of these (Flade Bugt; Fig. 3) an oil seep was located in 1990 (Jensen \& 

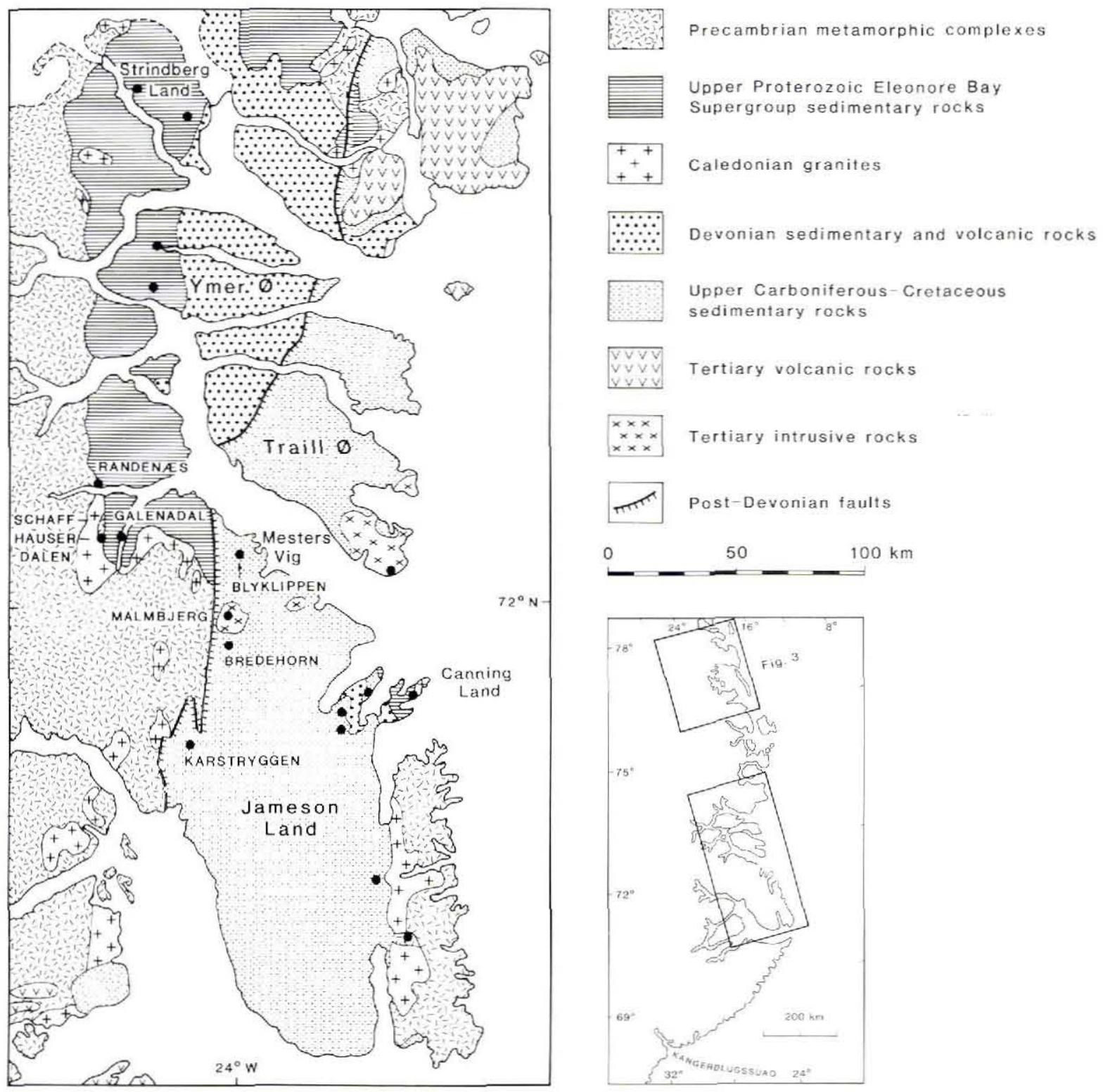

Fig. 1. Simplified geological map of central East Greenland and southern parts of North-East Greenland. Filled circles. localities for analysed lead isotope samples.

Stendal. 1990). The oily material appears to have migrated along the fault zone from buried oil-generating rocks or oil accumulations (Christiansen et al., 1991).

The aim of the lead isotope study is to characterise the sources of lead in the major types of mineralisation in East Greenland. Lead isotope compositions have been analysed for $c$. 250 samples of a variety of mineralised rocks, from mineral showings to economic ore deposits. The new analyses reported on here represent four groups of mineralisation in East Greenland: (1) stratiform and stratabound mineralisation in quartzites and shales of the Upper Proterozoic Eleonore Bay Supergroup; (2) mineralisation associated with Caledonian granites and Caledonian thrust and shear zones; (3) stratiform and stratabound mineralisation in Upper Carboniferous to Triassic sediments in central East Greenland; and (4) mineralisation in Tertiary igneous rocks. This paper gives a brief account of the new lead isotope data and some implications of their interpretation. Detailed treatment of the mineral occurrences and lead isotope data will be presented elsewhere. 
Fig. 2. ${ }^{207} \mathrm{~Pb} /{ }^{3 / 4} \mathrm{~Pb}-{ }^{216} \mathrm{~Pb} /{ }^{264} \mathrm{~Pb}$ compositional fields for EBS-hosted mineralisation. Solid black fields, Randenas Calcdonian pegmatite-hosted and vein-type mineralisitions plot in fields of Calcdonian granitc and Middle Pro. terozoic gneisses (Schaffhauserdalen type), respectively, and with Galenadal data define the Randena's mixing line. Mixing line data also define a linear array in a ${ }^{218} \mathrm{~Pb} /{ }^{214} \mathrm{~Pb}-{ }^{216} \mathrm{~Pb} /{ }^{20.1} \mathrm{~Pb}$ diagram (not shown); isochron data ( $E B S$ sedimentary silicates and EBS stratiform and Strindberg Land veins) do not. The average crust two-stage lead ewolution curve of Stacey \& Kramers (1975) is shown for comparison (ticks on curve mark 250 Ma intervals). Sce text for further discussion.

\section{Mineralisation in Eleonore Bay Supergroup (EBS) rocks}

Stratiform copper mineralisation is very widespread in certain beds of the Upper Proterozoic Eleonore Bay Supergroup (EBS), but has generally produced lowgrade occurrences (Stendal \& Ghisler, 1984). The same mineralised beds can outcrop as much as $275 \mathrm{~km}$ apart (Fig. 1). Shaly heds host disseminated chalcopyrite-pyrite, bornite-chalcocite or chalcocite assemblages, whereas quartzitic beds host chalcopyrite-pyrite-pyrrhotite or chalcopyrite-pyrite-tetrahedrite (Stendal \& Ghisler, 1984).

FBS rocks also host skarn and vein-type tungstenarsenic mineralisation believed to be of Caledonian age. The skirns are associated with Caledonian granites inIruded into the border zone between EBS rocks and the Precambrian metamorphic complexes (Fig. 1). Mineraliscd veins and breccias of uncertain origin are found in Strindberg Land and on Ymer $\varnothing$.

\section{Siratiform EBS mineralisation}

Copper sulphide (chalcocite) samples from stratiform mineralisation in Strindberg Land, Ymer $\emptyset$ and Canning Land (Fig. 1) have been analysed for their lead isotope compositions. Twelve chalcocite samples represent primary disseminated mineralisation in finegrained silicified carbonaceous shales and secondary remobilisation into stratabound veinlets and veins. The lead in the chalcocite samples is radiogenic with ${ }^{2 k} \mathrm{~Pb} /{ }^{04} \mathrm{~Pb}$ ratios ranging from 18.5 to 26.4 . In a ${ }^{207} \mathrm{~Pb}$ ${ }^{204} \mathrm{~Pb}-{ }^{2(k} \mathrm{Pb} /{ }^{2)} \mathrm{Pb}$ diagram (Fig. 2) the data points define a secondary isochron that indicates a primary mineralisation age of $680 \pm 65 \mathrm{Ma}$ (MSWD $=0.25$; all isochron ages are stated at the 20 level of confidence). This is a reatsonable estimate. as the mineralisation is regarded as being syn-diagenetic and of Late Precambrian to Early Cambrian age (Ghisler et al., 1980; Stendal \& Ghisler, 1984).

The somewhat radiogenic character of the sulphide lead is not uncommon for sediment-hosted mineralisation (cf. Bjorlykke \& Thorpe. 1981; Gulson. 1986). In three samples of mineralised EBS shale the lead isotope composition of the silicate matrix was measured after the sulphides had been leached out with $\mathrm{HNO}_{3}$. The silicate residues have strongly radiogenic compositions $\left({ }^{266} \mathrm{~Pb} /{ }^{2 i, 4} \mathrm{~Pb}\right.$ ratios from 21.4 to 55.1$)$ and fir a line with a slope of $0.0702 \pm 0.000$ ) quite well (MSWD $=$ 0.46). If tentatively treated as an isochron (only three points give little confidence), the slope of the line suggests derivation of the sedinent from a basement source with an age of $930 \pm 25$ Ma. Four galena samples from the Schaffhauscrdalen mineralisation in Middle Proterozoic paragneisses adjacent to the large area of EBS rocks (Fig. 1) plot exactly on the allegcd silicate matrix isocbron (Fig. 2).

\section{EBS intruded by Caledonian granites}

Mincralisation associated with Caledonian granites intruded into Eleonore Bay Supergroup rocks is represcnted by samples from Caming Land and Randencs (Fig. 1).

In Canning Land lead-zinc mineralisation is found in the hydrothermally altered rool zone of the Caledonian Kap Wardaw granite, and arsenic-lead-mineralised veins occur in the EBS country rock (Thomassen \& Schonwandt, 1981; Harpøth et al., 1986). The ${ }^{206} \mathrm{~Pb} /{ }^{04} \mathrm{~Pb}$ ratios of eight analysed samples range from 18.5 to 19.0 and the ${ }^{307} \mathrm{~Pb} /{ }^{24} \mathrm{~Pb}$ ratios are about 15.6 (Fig. 2). The ${ }^{20 \mathrm{~Pb}} \mathrm{~Pb} /{ }^{2)} \mathrm{pb}$ ratios range from 38.4 to 38.8 

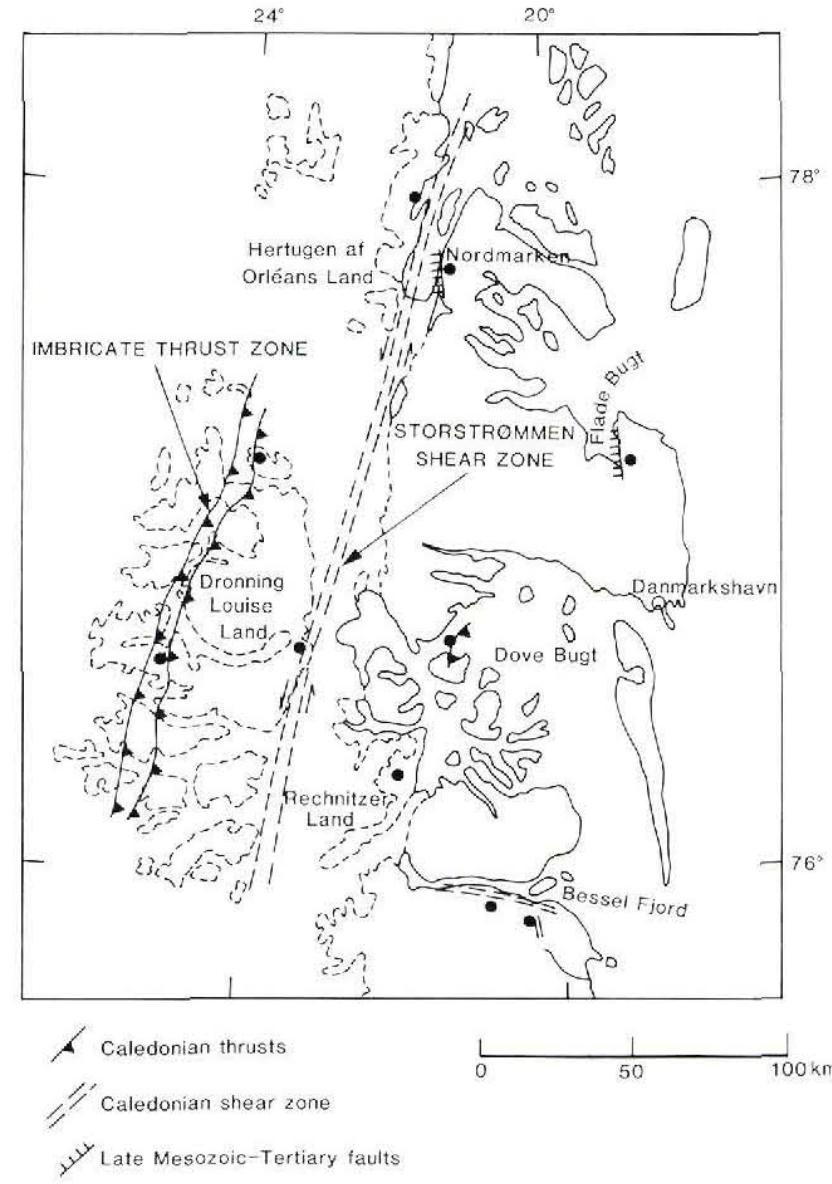

Fig. 3. Map of North-East Greenland $\left(76^{\circ}-78^{\circ} \mathrm{N}\right)$. Filled circles, new lead isotope data. Open circle, Danmarkshavn banded gneisses dated by Steiger et al. (1976).

At present these ranges best describe a 'Caledonian granite lead isotope composition?

Randenzes is located where Caledonian granites and pegmatites have intruded the contact zone between Lower Eleonore Bay Supergroup rocks and Middle Proterozoic paragneisses. Tungsten-tin and arsenic mineralisation in this area is associated with greisen zones in the pegmatites, and galena-arsenopyrite-bearing quartz veins occur in the EBS rocks (Lind, 1980); Harpoth et al., 1986). In a ${ }^{207} \mathrm{~Pb} /{ }^{204} \mathrm{~Pb}-{ }^{206} \mathrm{~Pb} /{ }^{204} \mathrm{~Pb}$ diagram data points for two pegmatite-hosted arsenopyrite samples plot in the Caledonian granite field whereas lead in two vein samples resembles the Schaffhauserdalen gneisshosted type of lead (Fig. 2). The Randenæs samples appear to approximate the two end member compositions of a mixing line between Caledonian granite lead and lead mobilised from Middle Proterozoic gneisses. The line has a slope of $0.0947 \pm 0.0064(\mathrm{n}=4$, MSWD $=0.12$ ). Four samples from a scheelite-arsenopyritebearing quartz vein swarm at Galenadal thought to be related to underlying Caledonian granites (Fig. 1), plot in a cluster on the Randenæs mixing line (Fig. 2). The Galenadal mineralisation, like the Randenæs veins, probably contains a significant component of unradiogenic lead derived from Middle Proterozoic basement gneisses mixed with Caledonian granite lead. Stratiform EBS-type lead does not appear to be significantly involved in mineralisation at Randenæs and Galenadal.

\section{Caledonian EBS-hosted veins and breccias of uncertain origin}

Caledonian vein- and breccia-type mineral occurrences in Eleonore Bay Supergroup rocks in which no field relation to Caledonian granites has been demonstrated include those of Strindberg Land and Y mer $\varnothing$ (Fig. 1).

The field of lead isotope compositions in Strindberg Land veins completely overlaps that of the stratiform EBS type, while the Ymer $\varnothing$ lead compositions $(n=7)$ are less radiogenic (Fig. 2). This suggests that the copper-rich Strindberg Land veins largely contain metals remobilised locally from the EBS-hosted stratiform mineralisation. In the tungsten-antimony-gold mineralisation on Ymer $\varnothing$ a non-EBS lead component is present.

On the basis of the lead isotope compositional fields for stratiform and Caledonian granite-related EBShosted mineralisation discussed above, possible mixing between end member components in vein mineralisation on Ymer $\varnothing$ can be assessed. If, for example. Caledonian granite is considered to have contributed lead in any significant amount to lead mobilised from the stratiform mineralisation, the mixing should produce leads with isotope ratios intermediate between the two types. For the Ymer $\varnothing$ mineralisation this is not an obvious interpretation. Instead, the field of Ymer $\varnothing$ lead extends towards compositions typical of Middle Proterozoic basement (e.g. Schaffhauserdalen type; Fig. 2). Caledonian metamorphic mobilisation of gneiss lead, mixing of the metamorphic fluid with lead mobilised from EBS-hosted stratiform mineralisation, and deposition of scheelite and sulphides in veins and breccias in the EBS rocks may have produced the observed lead isotope signature.

\section{Mineralisation in North-East Greenland $\left(76^{\circ}-\right.$ $78^{\circ} \mathrm{N}$ )}

In North-East Greenland Caledonian mineralisation is related to thrust and shear zones. These include the Bessel Fjord and Storstrømmen shear zones, the imbri- 
Fig. 4. ${ }^{207} \mathrm{~Pb} /{ }^{204} \mathrm{~Pb}-{ }^{210} \mathrm{~Pb} /{ }^{204} \mathrm{~Pb}$ diagram showing isochrons and compositional fields for mincralisation in North-East Greenland $\left(76^{\circ}-78^{\circ} \mathrm{N}\right)$. Precambrian skarns, undeformed Lower Proterozoic skarns in Rechnitzer I.and and on islands in Dove Bugl. Shear zone, islands in Dove Bugi, strongly radiogenic samples define isochron for Caledonian deformation and uranium influx. $\mathrm{lm}$ bricute thrust zone, hematitised samples define isochron for Caledonian thrusting and hematitisation. Bessel Fiord, Storstrommen, Caledonian shear zones have mobilised lead from Middle Proterozoic sources. Flade Bugt-Nordmarken, pyrite mineralisation in Upper Mesozoic - Tertiary fault breccias has incorporated lead with Archaean source age.

\section{${ }^{207} \mathrm{~Pb} /{ }^{204} \mathrm{~Pb}$}

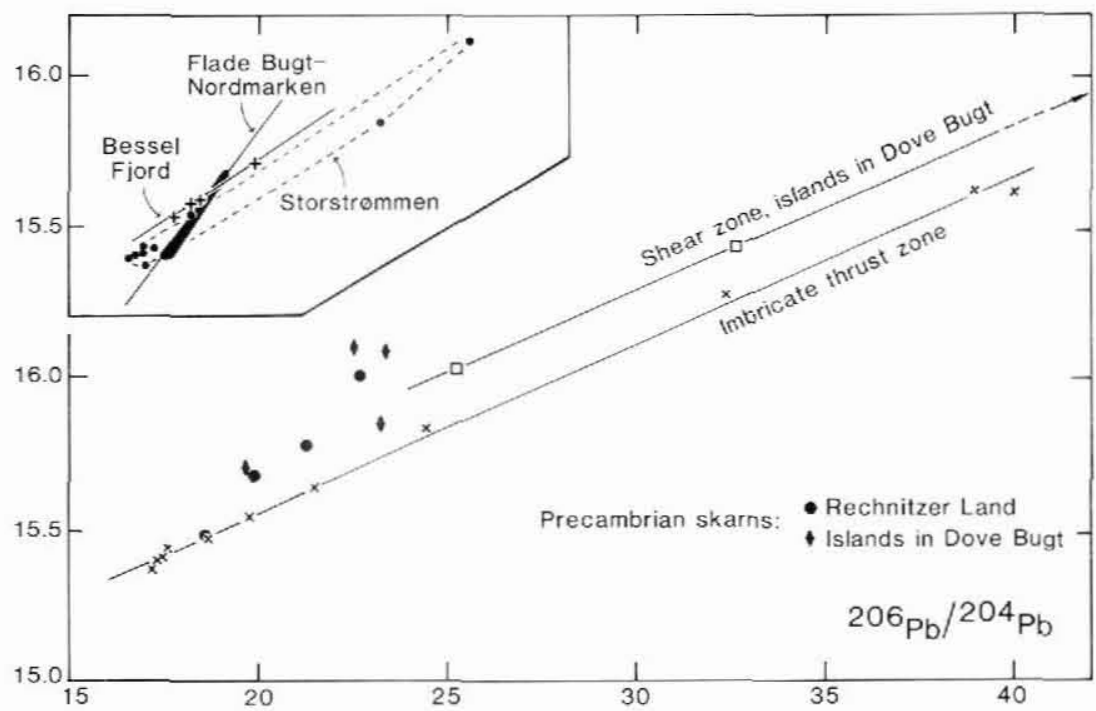

cate thrust zone of Dronning Louise Land and a sheared and imbricated Lower to Middle Proterozoic contact skarn on two small islands in Dove Bugt (Fig. 3).

On the islands in Dove Bugt a Precambrian skarn mineralisation at the contact between a pink orthogneiss and paragneisses was sheared and imbricated during the Caledonian orogeny. producing a very complex structure with alternating lenses of magnetite-hornblende, garnet-quartz-fluorite and marble skarns. Mineral separates from an As- $\mathrm{Zn}-\mathrm{U}$-Th-Be-enriched marble sample (GGU 365156) are moderately to extremely radiogenic $\left({ }^{206} \mathrm{~Pb} /{ }^{04} \mathrm{~Pb}\right.$ ratios from 19.7 to c. 77000$)$ and define an isochron that corresponds to an age of $396 \pm 3$ Ma $(n=7$, MSWD $=0.59)$ (Fig. 4). This is interpreted as the age of deformation of the Precambrian skarn and the time of introduction of uranium along the shear zone. Samples from hornblende-magnetite-rich parts of the skarn zone have compositions that resemble those of a Lower to Middle Proterozoic skarn occurrence in Rechnitzer Land (Fig. 4).

Caledonian uranium influx is also evident in the imbricate thrust zone of Dronning Louise Land. The imbricate zone is defined by several east-dipping thrust sheets that are composed of basement gneisses and a strongly sheared Middle to Late Precambrian metasedimentary cover sequence (Friderichsen et al., 1990). Iron-rich metasediments and amphibolites in the imbricate zone are pervasively hematitised. Hematite-rich samples from two localities in the imbricate zone, $70 \mathrm{~km}$ apart, together define a linear array roughly parallel to that determined for the islands in Dove Bugt (Fig. 4). Its slope corresponds to a mincralisation age of $435 \pm 75$
Ma $(\mathrm{n}=11$, MSWD $=3.03)$. Metamorphic oxidising fluids are considered to have migrated along the thrust planes to cause the hematitisation and supply the uranium incorporated in the hematite crystals.

Two groups of isochron-determined maximum source ages in North-East Greenland pre-dating the Caledonian emerge from the lead isotope data: Middle Proterozoic $(\sim 1200 \mathrm{Ma})$ and Late Archaean - Early Proterozoic $(2000-2500 \mathrm{Ma})$

Middle Proterozoic lead source ages were obtained for lead in pyrite disseminated in the Bessel Fjord and Storstrømmen shear zones. The Storstrømmen shear zone separates Dronning Louise Land from the coastal region and continues some $300 \mathrm{~km}$ northwards into Hertugen af Orléans Land (Fig. 3) (Strachan et al.. 1991).

Samples from the Bessel Fjord shear zone define an isochron that corresponds to a maximum source age of $1220 \pm 180 \mathrm{Ma}(\mathrm{n}=5$. MSWD $=0.15)($ Fig. 4). $\mathrm{A}$ roughly parallel array is defined by ten samples from the Storstrømmen shear zone, but they scatter considerably more. If a Caledonian mineralisation age of $400 \mathrm{Ma}$ is assumed and used in isochron calculations, a source age of about $900 \mathrm{Ma}$ is indicated. This corresponds to a Grenville age for the crustal reservoir that supplied the lead in the pyrites.

Late Archacan - Early Proterozoic lead source ages are indicated for the Upper Mesozoic to Tertiary fault breccia pyrite mineralisation in Flade Bugt and Nordmarken (Figs 3 \& 4); ten samples define an isochron age of $2475 \pm 160 \mathrm{Ma}(\mathrm{MSWD}=1.33)$. The presence of Archaean $(\sim 3000 \mathrm{Ma})$ crustal material in North-East 
Greenland was reported by Steiger et al. (1976) from isotopic studies on a banded gneiss from the Danmarkshavn area (Fig. 3). Further, Kalsbeek et al. (1993) present new $\mathrm{Rb}-\mathrm{Sr}$, Sm-Nd and U-Pb isotopic dating results which demonstrate that major crustal growth took place in the region $\sim 2000 \mathrm{Ma}$ ago and that Archaean crust was incorporated into these rocks. The isotopic composition of lead in pyrite in the late fault breccias thus suggests derivation from the local basement gneisses.

\section{Mineralisation in Upper Palaeozoic to Mesozoic rocks}

Stratabound vein type $\mathrm{Pb}-\mathrm{Zn}-\mathrm{Cu}-\mathrm{Ba}$ mineral occurrences hosted in sedimentary rocks of Upper Carboniferous to Triassic age are widespread in central East Greenland, especially along the margins of the Jameson Land sedimentary basin.

The largest deposits are situated along the major post-Devonian fault system that separates Upper Palaeozoic and younger rocks from Caledonian and older rocks (Fig. 1). At Blyklippen $\mathrm{Pb}-\mathrm{Zn}$-Ba-mineralised quartz veins occur in Upper Carboniferous and Lower Permian arenaceous rocks. At nearby Oksedal and at Bredehorn stratabound replacement and vein mineralisation is hosted by Upper Permian carbonate rocks. Upper Permian carbonates host a major celestite $\left(\mathrm{SrSO}_{4}\right)$ deposit at Karstryggen (Scholle et al., 1990); minor $\mathrm{Pb}-\mathrm{Zn}$-Ba showings occur here as well (Harpøth et al., 1986). Although the mineralisation exposed at these localities varies in style and age and composition of host rocks, the occurrences all have similar lead isotope compositions. Analyses of $c .50$ mineralised samples show isotope ratios within the ranges 18.25$18.45\left({ }^{206} \mathrm{~Pb} /{ }^{204} \mathrm{~Pb}\right), 15.50-15.60\left({ }^{207} \mathrm{~Pb} /{ }^{204} \mathrm{~Pb}\right)$ and 38.10 $38.30\left({ }^{208} \mathrm{~Pb} /{ }^{204} \mathrm{~Pb}\right)$.

Stratabound and stratiform $\mathrm{Cu}-\mathrm{Pb}-\mathrm{Zn}$ mineralisation in Upper Permian to Triassic sediments in eastern Jameson Land (see Thomassen et al., 1982) has a slightly more radiogenic lead isotope signature $\left({ }^{206} \mathrm{~Pb} /{ }^{04} \mathrm{~Pb}\right.$ $18.45-18.60, \mathrm{n}=19)$ and displays greater variation in the ratios ${ }^{207} \mathrm{~Pb} /{ }^{204} \mathrm{~Pb}(15.55-15.70)$ and ${ }^{208} \mathrm{~Pb} /{ }^{204} \mathrm{~Pb}$ (38.2-38.8).

One possible cause for the homogeneity of lead isotope compositions of the replacement- and vein-type mineral occurrences is their proximity to the major faults bounding the Jameson Land basin. The faults may have acted as a 'plumbing system' conducting mineralising fluids from depth. The lead source is probably the sedimentary rocks in the deeper parts of the Jameson Land basin, and mineralisation could have been triggered by fault movements in the Upper Permian or Lower Triassic.
Other possible agents of mineralisation that merit consideration include Lower Tertiary basaltic sills and dykes. Sills outcropping along the margins of the Jameson Land basin are commonly $10-50 \mathrm{~m}$ thick, and up to $300 \mathrm{~m}$ thick sills appear to have intruded the deep, central parts of the basin (Larsen \& Marcussen, 1992). The sills could have provided the heat necessary to drive very large hydrothermal systems in the sedimentary ba$\sin$.

\section{Mineralisation in Tertiary igneous rocks}

The Malmbjerg porphyry-molybdenum deposit in central East Greenland and the Flammefjeld molybdenum-precious metal prospect in the Kangerdlugssuaq region (Fig. 1) are late intrusive phases in continental rifting-related alkaline magmatic complexes. The Tertiary Skaergaard intrusion and other layered gabbroic intrusions in the Kangerdlugssuaq area have recently been found to host gold and platinum group element mineralisation (Nielsen, 1990; Nielsen \& Schønwandt, 1990; Bird et al., 1991).

The Kangerdlugssuaq gneisses, the country rocks to the Skaergaard intrusion, have been dated using the $\mathrm{Pb}-\mathrm{Pb}$ system (Leeman et al., 1976). Seven whole-rock lead isotope analyses yielded a ${ }^{207} \mathrm{~Pb} /{ }^{006} \mathrm{~Pb}$ secondary isochron corresponding to an age of c. $3000 \mathrm{Ma}$ (Fig. 5). In a subsequent isotope study it was shown that gabbros and granophyric dykes from the Skaergaard intrusion also define a linear array in the ${ }^{207} \mathrm{~Pb} /{ }^{204} \mathrm{~Pb}^{206} \mathrm{~Pb} /{ }^{204} \mathrm{~Pb}$ diagram (Leeman \& Dasch, 1978). The array lies below the gneiss isochron and has a lower slope (Fig. 5). It was interpreted as a mixing line between a low $\mu\left({ }^{238} \mathrm{U} /{ }^{204} \mathrm{~Pb}\right)$ crustal source and a Tertiary mantle-derived source. Low $\mu$ values are typical of uranium-depleted, granulite facies rocks. Contamination with Archaean high-grade metamorphic crustal material of the mantle-derived magma was considered to have occurred at a deep crustal level. The Tertiary mantle-derived component was considered comparable to lead in a Malmbjerg galena sample.

New lead isotope data lend support to this interpretation. Sixteen Flammefjeld samples (pyrite from molybdenum-mineralised intrusion breccias and galena from quartz-carbonate-galena-sphalerite veins) have compositions that plot exactly on the Skaergaard mixing line (Fig. 5). In a ${ }^{208} \mathrm{~Pb} /{ }^{204} \mathrm{~Pb}-{ }^{206} \mathrm{~Pb} /{ }^{204} \mathrm{~Pb}$ diagram (not shown) the Skaergaard instrusion and Flammefjeld samples also define linear arrays that include the field for the Tertiary mantle-derived component. This suggests that both Flammefjeld and Skaergaard magmas were contaminated with low- $\mu$ Archaean lower crustal lead. 
Fig. 5. ${ }^{207} \mathrm{~Pb} /{ }^{204} \mathrm{~Pb}-{ }^{216} \mathrm{~Pb} /{ }^{204} \mathrm{~Pb}$ compositional fields for mineralisation in Tertiary igneous rocks shown with whole-rock lead isotope data from the Kangerdlugssuaq region. Flammefjeld and Central East Greenland prospects, new analyses. $A$, Kangerdlugssuaq gneiss isochron (Leeman et al., 1976); filled circles, samples included in isochron calculation: open circle, sample excluded from calculation. $B$, Skatgaard intrusion mixing line (Leeman \& Dasch, 1978); filled triangles, granophyres from Skaergaard intrusion; filled squares. Skaergaard intrusion gabbros. $S \& K$, average crust two-stage lead evolution curve (Stacey \& Kramers, 1975).

Lead isotope compositions for mineralisation in Tertiary igneous rocks in central East Grcenland are distinct from those of the Kangerdlugssuaq area (Fig. 5). The field for 'central East Greenland prospects' ( $n=18$ ) coincides with the Tertiary mantle-derived component of the Skaergaard intrusion mixing line proposed by Leeman \& Dasch (1978). The Malmbjerg molybdenum deposit and other sulphide concentrations in Tertiary igneous rocks in central East Greenland do not show lead isotope evidence for contamination with an $\mathrm{Ar}$ chaean lower crustal component although their ages, geotectonic setting and possibly modes of mineralisation are similar to those of the Tertiary intrusions in the Kangerdlugssuac area.

\section{Conclusions}

Lead isotope compositions of mincral occurrences in East Greenland clearly reflect the geological settings of mineralisation. Stratiform and stratabound mineral occurrences have distinct isotopic patterns that attest to the large-scale nature of the mineralising systems that formed them. Caledonian and Tertiary magmatic-influenced mineralisations also have distinct compositions. Local basement remobilisation is often evident in veintype mineralisation. Lead mixing with involvement of an unradiogenic low- $\mu$ crustal end member is encountered in mineralisation throughout East Greenland, and the presence of Late Archacan to Lower Proterozoic crust in large parts of the Caledonian fold belt is confirmed by several ${ }^{217} \mathrm{~Pb} /{ }^{206} \mathrm{~Pb}$ isochrons.

Stratiform mineralisation in the Upper Proterozoic Eleonore Bay Supergroup has a somewhat radiogenic lead isotopic signature in accord with syn-diagenetic leaching of the metals (mainly copper) from upper crus- tal rocks. Where Caledonian granites have intruded EBS rocks, the associated skarn mineralisation may have derived most of the lead from the granites.

For vein-type mineralisation hosted in EBS rocks, such as the Strindberg Land and Ymer $\varnothing$ prospects, the lead isotope signatures suggest a significant component of lead derived locally from the stratiform mineralisation in the EBS. In the Ymer $\varnothing$ prospects this type of lead appears to have been mixed with lead mobilised from underlying Middle Proterozoic gneisses introduced along deep-rooted faults.

Stratabound replacement and vein mineralisation in Upper Carboniferous to Upper Permian sediments, localised along the major post-Devonian fault system bounding the Jameson Land basin, shows little lead isotopic variation. The mineralisation appears to be structurally controlled by the fault system. and may have been triggered by faulting or by the intrusion of Tertiary basaltic sills and dykes in the sedimentary ba$\sin$. Based on the present lead isotope data base it is not possible to conclude whether the mincralisation is Upper Permian or Tertiary in age.

Mineralisation in Tertiary igneous rocks shows distinct lead isotopic signatures. At Flammefjeld in the Kangerdlugssuaq area the unradiogenic lead isotope signature is the result of mixing of lead from two endmember sources: Archaean high-grade gneisses of the lower crust and Tertiary mantle-derived magmas. The lead isotope signature for mineralisation in the Tertiary igneous rocks of central East Grecnland does not suggest mixing with an old crustal source.

Note on analytical procedure. Samples of galena and other sulphides were dissolved in $\mathrm{HNO}_{3}$, and hematite samples in $\mathrm{HC}$. Lead in trace amounts was subsequently extracted from a 
$\mathrm{HBr}$ solution in anion ion exchange columns. Samples were loaded with silica gel in $\mathrm{H}_{3} \mathrm{PO}_{4}$ on single rhenium filaments and ionised at $1230^{\circ} \mathrm{C}$ in a Finnigan MAT-261 multiple-collector mass spectrometer. The NBS SRM 981 lead standard was measured frequently and compared to the 'true' value of Todt et al. (1984). The mass fractionation factors for the ratios ${ }^{206} \mathrm{~Pb} /{ }^{204} \mathrm{~Pb},{ }^{207} \mathrm{~Pb} /{ }^{204} \mathrm{~Pb}$ and ${ }^{208} \mathrm{~Pb} /{ }^{204} \mathrm{~Pb}$ are $1.0025,1.0037$ and 1.0050 , respectively. Total errors for the lead isotope ratios are considered smaller than $0.10 \%$. Analytical data will be published elsewhere.

Acknowledgements. The work presented here is part of a Ph.D. study being undertaken at the Department of Geology, University of Aarhus and the Geological Survey of Greenland. The field work in North-East Greenland was carried out by $\mathbf{H}$. Stendal, University of Copenhagen and the author as members of the GGU North-East Greenland Expedition 1990. Lead isotope analyses were obtained at the Department of Geology and Geophysics, Rice University, Houston, Texas. J. E. Wright kindly provided analytical facilities. J. Wen and R. L. Romer are thanked for a thorough introduction to isotope laboratory routines. Financing was possible through grants from the Danish Natural Science Research Council and the Danish Research Academy.

\section{References}

Bird, D. K., Brooks, C. K., Gannicott, R. A. \& Turner, P. A. 1991: A gold-bearing horizon in the Skaergaard intrusion, East Greenland. Econ. Geol, 86, 1083-1092.

Bjørlykke, A. \& Thorpe, R. I. 1982: The source of lead in the Osen sandstone lead deposit on the Baltic Shield, Norway. Econ. Geol. 77, 430-440.

Christiansen, F. G., Bojesen-Koefoed, J., Jensen, S. M. \& Stemmerik, L. 1991: Oil seep in basement, Germania Land, North-East Greenland. Open File Ser. Grønlands geol. Unders. 91/7, $18 \mathrm{pp}$.

Friderichsen, J. D., Holdsworth, R. E., Jepsen, H. F. \& Strachan, R. A. 1990: Caledonian and pre-Caledonian geology of Dronning Louise Land, North-East Greenland. Rapp. Grønlands geol. Unders. 148, 133-141.

Geyti, A. \& Thomassen, B. 1984: Molybdenum and precious metal mineralization at Flammefjeld, Southeast Greenland. Econ. Geol. 79, 1921-1929.

Ghisler, M., Jensen, Aa., Stendal, H. \& Urban H. 1980: Stratabound copper mineralization in the Late Precambrian of the East Greenland Caledonides. In Janković, S. \& Sillitoe, R. H. (ed.) European copper deposits. Spec. Publ. Soc. Geol. Appl. Miner. Deposits 1, 160-165.

Gulson, B. L. 1986: Lead isotopes in mineral exploration, 245 pp. Amsterdam: Elsevier

Harpøth, O., Pedersen, J. L., Schønwandt, H. K. \& Thomassen, B. 1986: The mineral occurrences of central East Greenland. Meddr Grønland Geosci. 17, $139 \mathrm{pp}$.

Henriksen, N. 1991: The North-East Greenland project 19881990. Rapp. Grønlands geol. Unders. 152, 24-29.

Jensen, S. M. \& Stendal, H. 1990: Geochemical and ore geological field investigations in North-East Greenland (76 - $78^{\circ} \mathrm{N}$ ). Express Report North-East Greenland 1990. Unpubl. intern. GGU rep., 49-55.

Kalsbeek, F., Nutman, A. P. \& Taylor, P. N. 1993: Early Proterozoic basement province in the Caledonian fold belt of North-East Greenland. Precambrian Res. (in press).

Larsen, H. C. \& Marcussen, C. 1992: Sill-intrusion, flood basalt emplacement and deep crustal structure of the Scoresby Sund region, East Greenland. In Storey, B. C., Alabaster, T. \& Pankhurst, R. J. (ed.) Magmatism and the causes of continental break-up. Spec. Publ. geol. Soc. Lond. 68, 365-386.

Leeman, W. P. \& Dasch, E. J. 1978: Strontium, lead and oxygen isotopic investigation of the Skaergaard intrusion, East Greenland. Earth Planet. Sci. Lett, 41, 47-59.

Leeman, W. P., Dasch, E. J. \& Kays, M. A. 1976: ${ }^{207} \mathrm{~Pb} /{ }^{206} \mathrm{~Pb}$ whole-rock age of gneisses from the Kangerdlugssuaq area, eastern Greenland. Nature 263, 469-471.

Lind, M. 1980: Scheelitprospektering i Forsblads Fjord, Alpefjord, Jelsdal, Ymers $\emptyset$ og Kalkdal. Unpubl. intern. rep., Nordisk Mineselskab A/S, $58 \mathrm{pp}$.

Nielsen, T. F. D. 1990: A gold mine in East Greenland? Rapp. Grønlands geol. Unders. 148, 40-43.

Nielsen, T. F. D. \& Schønwandt, H. K. 1990: Gold and platinum group metal mineralisation in the Skaergaard intrusion, southern East Greenland. Rapp. Grønlands geol. Unders. 148, 101-103.

Scholle, P. A., Stemmerik, L. \& Harpøth, O. 1990: Origin of major karst-associated celestite mineralization in Karstryggen, central East Greenland. J. Sed. Petrol. 60, 397-410.

Sch $\varnothing$ nwandt, H. K. 1991: Economic mineral resources: activities in 1990. Rapp. Grønlands geol. Unders. 152, 41-46.

Stacey, J. S. \& Kramers, J. D. 1975: Approximation of terrestrial lead isotope evolution by a two-stage model. Earth Planet. Sci. Lett. 26, 207-221.

Steiger, R. H., Harnik-Šoptrajanova, G., Zimmermann, E. \& Henriksen, N. 1976: Isotopic age and metamorphic history of the banded gneiss at Danmarkshavn, East Greenland. Contr. Miner. Petrol. 57, 1-24.

Stendal, H. \& Ghisler, M. 1984: Strata-bound copper sulfide and nonstrata-bound arsenopyrite and base metal mineralization in the Caledonides of East Greenland - a review. Econ. Geol. 79, 1574-1584.

Stenstrop, G. 1989: Anorogenic complexes associated with molybdenum mineralizations. Unpubl. Ph.D. thesis, Department of Earth Sciences, University of Aarhus, 191 pp.

Strachan, R. A., Jepsen, H. F. \& Kalsbeek, F. 1991: Regional Caledonian structure of Hertugen af Orléans Land, NorthEast Greenland. Rapp. Gronlands geol. Unders. 152, 95-102.

Thomassen, B. \& Schønwandt, H. K. 1981: Prospecting for $\mathrm{Cu}-\mathrm{Pb}-\mathrm{Zn}-\mathrm{Ag}-\mathrm{Au}$ in the Upper Permian sediments and Devonian volcanics of East Greenland. Unpubl. intern. rep., Nordisk Mineselskab A/S, 100 pp.

Thomassen, B., Clemmensen, L. B. \& Schønwandt, H. K. 1982: Stratabound copper-lead-zinc mineralisation in the Permo-Triassic of central East Greenland. Bull. Grønlands geol. Unders. 143, $42 \mathrm{pp}$.

Todt, W., Cliff, R. A., Hanser, A. \& Hoffmann, A. W. 1984: ${ }^{202} \mathrm{~Pb}+{ }^{205} \mathrm{~Pb}$ double spike for lead isotopic analyses. Terra Cognita 4(2), 209 (1 only). 